\title{
A Nested-Splicing by Overlap Extension PCR Improves Specificity of this Standard Method
}

\author{
Ali Asghar Karkhane *, Bagher Yakhchali, Ferdous Rastgar Jazii, Bijan Bambai, Saeed Aminzadeh, \\ Fatemeh Rahimi
}

Department of Industrial and Environmental Biotechnology, National Institute of Genetic Engineering and Biotechnology (NIGEB), Tehran, Iran

\begin{abstract}
*Corresponding Author: Ali Asghar Karkhane, Department of Industrial and Environmental Biotechnology, National Institute of Genetic Engineering and Biotechnology (NIGEB), Tehran, Iran. Tel: +98-44787360, Fax: +98-44787395, E-mail: karkhane@nigeb.ac.ir
\end{abstract}

Received: November 30, 2014; Revised: February 18, 2015; Accepted: April 29, 2015

\begin{abstract}
Background: Splicing by overlap extension (SOE) PCR is used to create mutation in the coding sequence of an enzyme in order to study the role of specific residues in protein's structure and function.

Objectives: We introduced a nested-SOE-PCR (N -SOE-PCR) in order to increase the specificity and generating mutations in a gene by SOE-PCR.

Materials and Methods: Genomic DNA from Bacillus thermocatenulatus was extracted. Nested PCR was used to amplify $B$. thermocatenulatus lipase gene variants, namely wild type and mutant, using gene specific and mutagenic specific primers, followed by cloning in a suitable vector. Briefly in N-SOE-PCR method, instead of two pairs of primers, three pairs of primers are used to amplify a mutagenic fragment. Moreover, the first and second PCR products are slightly longer than PCR products in a conventional SOE. PCR products obtained from the first round of PCR are used for the second PCR by applying the nested and mutated primers. Following to the purification of the amplified fragments, they will be subject of the further purification and will be used as template to perform the third round of PCR using gene specific primers. In the end, the products will be cloned into a suitable vector for subsequent application.

Results: In comparison to the conventional SOE-PCR, the improved method (i.e. N-SOE-PCR) increases the yield and specificity of the products. In addition, the proposed method shows a large reduction in the non-specific products.

Conclusions: By applying two more primers in the conventional SOE, the specificity of the method will be improved. This would be in part due to annealing of the primers further inside the amplicon that increases both the efficiency and a better attachment of the primers. Positioning of the primer far from both ends of an amplicon leads to an enhanced binding as well as increased affinity in the third round of amplification in SOE.
\end{abstract}

Keywords: Nested-Splicing by Overlap Extension PCR; polymerase Chain Reaction; Site-directed mutagenesis

\section{Background}

Site-directed mutagenesis is widely used in molecular biology either in the studies related to the structure-function of proteins or for engineering of proteins that are useful and enhancement of the enzymes' activity or their resistance to the environmental conditions as well as chemicals $(1,2)$. A variety of methods that are based on polymerase chain reaction (PCR), including overlap extension, have been established for sitedirected mutagenesis (3-7). Splicing by overlap extension (SOE) provides a powerful method to generate recombinant sequences without a dependence on the restriction sites or ligases $(8,9)$. However, the major drawback of SOE is its low specificity in the amplifi- cation of the full size mutated fragment in the third PCR. In order to challenge this issue, in the present study we have introduced an improvement into the standard SOE method as we called it N-SOE method. This innovation has improved the specificity of mutagenesis.

A schematic presentation of the N-SOE method is depicted in Figure 1. In this method, three pairs of primers, namely $\mathrm{A}$ and $\mathrm{B}, \mathrm{C}$ and $\mathrm{D}$, and $\mathrm{E}$ plus $\mathrm{F}$, are used. Primers $\mathrm{C}$ and $\mathrm{D}$ are gene specific, and primers $\mathrm{E}$ and $\mathrm{F}$ are the mutated primers in a standard SOE method. Primers A and B are additional complementary primers that flank (i.e. locate to the outside) the standard SOE with respect to the primers $\mathrm{C}$ and D (or 
the gene specific primers). These two additional primers are dependent on the recombinant vector that harbors the gene (i.e. M13/PUC or T7 promoter universal primers). These primers are designed such that to position at least 50 to 70 base pairs outward from binding site of the nested primers $\mathrm{C}$ and $\mathrm{D}$.

The proposed procedure consists of four steps as follows: (i) The target gene is amplified by PCR using gene specific primers (nested primers $\mathrm{C}$ and $\mathrm{D}$ ) and is cloned into the vector (i.e. pTZ57R/T or pGEM).

(ii) The target gene in recombinant vector (0.1-0.2 ng) will be subjected to the first round of PCR using A and $F$ primers and the second PCR using E and B primers to amplify AF and EB fragments, respectively (FigUre 1).

(iii) The amplified fragments are purified and used as template to perform the third round of PCR by N-SOE method (Figure 1).

(iv) Equimolar amounts of the first and second PCR products (about $0.2 \mathrm{ng}$ ) and $10 \mathrm{pmol}$ of each $\mathrm{C}$ and $\mathrm{D}$ primers (nested primers) are added to the PCR reaction for overlap extension and amplification of the full length of the mutated gene (Figure 1). The first 10 cycles of the third PCR are performed with shorter

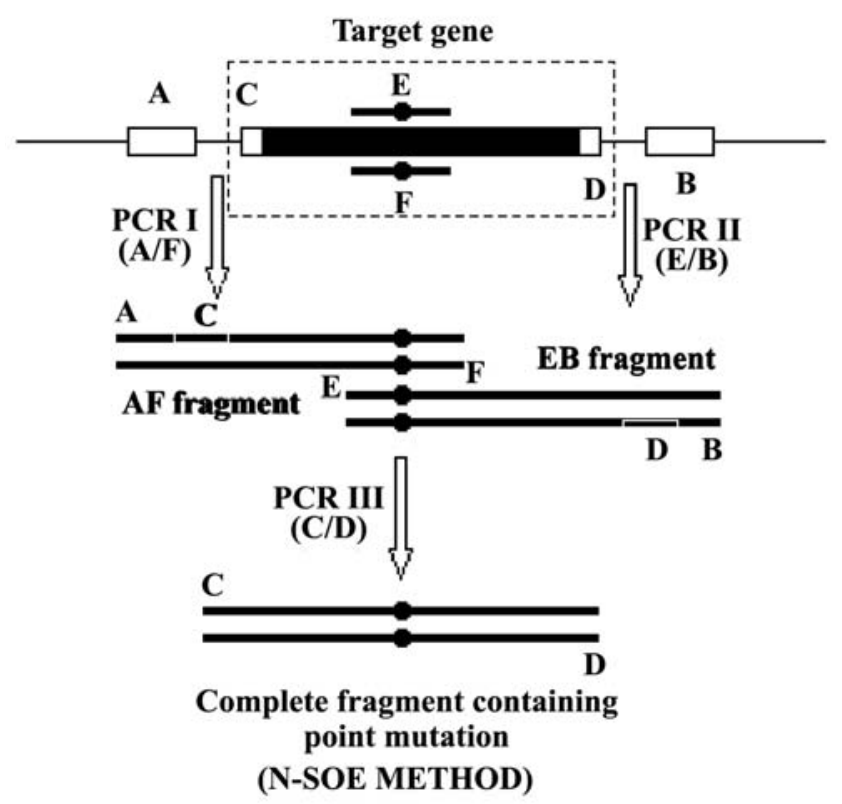

Figure 1. A schematic representation of the N-SOE method. $\mathrm{A}$ and $\mathrm{B}$ primers are the forward and the reverse primers designed according to flanking sequences of the target gene in the cloning vector (same as M13 universal primers). C and $\mathrm{D}$ primers are the gene specific primers (nested primers). $\mathrm{E}$ and $\mathrm{F}$ are primers which are subjected to the mutation. The black dots indicate the corresponding mutated nucleotides extension time at $68^{\circ} \mathrm{C}$, followed with 25 cycles with longer extension time at $72^{\circ} \mathrm{C}$. The full size of the mutagenized fragment will be purified from agarose gel and will be cloned into the cloning vector respectively.

To validate the specificity of the proposed N-SOE method, an experiment was designed in order to introduce a specific mutation in the Bacillus thermocatenulatus lipase gene (btl2) and compare it with the conventional SOE.

\section{Objectives}

The aim of the present study is to improve SOEPCR that is called N-SOE-PCR to enhance the specificity of mutagenesis.

\section{Materials and Methods}

\subsection{Cloning of the btl2 Gene}

Bacillus thermocatenulatus genomic DNA was extracted according to the method described by Sambrook et al. (2001). All the PCR reactions were performed in a final volume of $50 \mu \mathrm{L}$ containing 200 $\mu \mathrm{M}$ of each dNTP, $5 \mu \mathrm{L}$ of PCR buffer with a final concentration of $1.5 \mathrm{mM} \mathrm{MgCl}_{2}, 5 \%$ glycerol, 2 units $P f u$ DNA polymerase, $10 \mathrm{pmol}$ of each primer and 2 ng Bacillus thermocatenulatus genomic DNA as template. The lipase gene (btl2) was amplified by using the gene specific primers (primer $\mathrm{C} ; 5^{\prime}$-GATGGCCATGGCGGCATCCCCACGCGCC-3', Mlu NI site and primer D; 5'-TT GAGCTCATCATCCCTTCATTAAGGCCGC-3', SacI site) designed according to btl2 gene sequence (GenBank X95309). The PCR reaction was carried out in a thermocycler (Techne, UK) with the following settings: $4 \mathrm{~min}$ at $94^{\circ} \mathrm{C}, 1 \mathrm{~min}$ at $94^{\circ} \mathrm{C}, 1 \mathrm{~min}$ at $62^{\circ} \mathrm{C}$, and $1.5 \mathrm{~min}$ at $72^{\circ} \mathrm{C}$ ) for 30 cycles with a final cycle of $5 \mathrm{~min}$ at $72^{\circ} \mathrm{C}$. Subsequently, the amplified gene $(\sim 1200 \mathrm{bp})$ was cloned into pTZ57R/T vector leading to the formation of the pTA-BTL2 plasmid, which was introduced into $E$. coli $\mathrm{DH} 5 \alpha$.

\subsection{SOE and N-SOE-PCR Method}

The standard SOE and N-SOE-PCR methods were used in order to generate mutation in the $b t l 2$ gene. 2 ng of the recombinant pTZ-BTL2 plasmid was used as template in the first and second PCR reactions. In both methods, the first PCRs were performed by using the primer pairs of A and F (M13/pUC forward primer; $5^{\prime}$ TAAAACGACGGCCAGTGAATTCG- ${ }^{\prime}$ and the reverse mutated primer; 5' -CTGATCGCGCCTTTGACCTGC-3' . The mutated nucleotides are shown in bold respective- 
ly. The second PCR was performed by using the primer pairs of $\mathrm{E}$ and $\mathrm{B}$ such that the forward mutated primer was; 5'-GCTGGTCAAAGGCGCGATCAG-3' and the M13/pUC reverse primer was composed of $5^{\prime}-$ GAAACAGCTATGACCATGATTACG-3'). The first and second PCRs were performed under following the conditions: $2.5 \mathrm{~min}$ at $94^{\circ} \mathrm{C},\left(1 \mathrm{~min}\right.$ at $94^{\circ} \mathrm{C}, 1 \mathrm{~min}$ at $48^{\circ} \mathrm{C}$, and $45 \mathrm{sec}$ at $72^{\circ} \mathrm{C}$ ) for 30 cycles and a final step of $5 \mathrm{~min}$ at $72^{\circ} \mathrm{C}$. These two PCR fragments were purified using High Pure PCR Product Purification Kit (Roche, Germany) and served as a template for the subsequent third round of PCR. In the N-SOE method the third PCR is performed, whereas in the standard SOE method the third PCR is performed by addition of primer pairs of A and B to the PCR master mix just after 10 cycles of the third PCR amplification (Figure 1). In both methods, the third PCR was carried out using the following settings: $1.5 \mathrm{~min}$ at $94^{\circ} \mathrm{C},(45 \mathrm{sec}$ at $94^{\circ} \mathrm{C}, 1.5 \mathrm{~min}$ at $48^{\circ} \mathrm{C}$, and $45 \mathrm{sec}$ at $68^{\circ} \mathrm{C}$ ) for 10 cycles, and $\left(45 \mathrm{sec}\right.$ at $94^{\circ} \mathrm{C}, 1 \mathrm{~min}$ at $56^{\circ} \mathrm{C}$, and $1.5 \mathrm{~min}$ at $72^{\circ} \mathrm{C}$ ) for 25 cycles with a final cycle of $5 \mathrm{~min}$ at $72^{\circ} \mathrm{C}$. Subsequently, PCR product yield and quality was analyzed by agarose gel electrophoresis. All the PCR reactions were repeated four times.

\section{Results}

In the first and the second PCR reactions a $\sim 600 \mathrm{bp}$ (Figure 2A; lane a,) and a 740 bp (Figure 2A; lane b) fragments are amplified, respectively. These two PCR products were served as template for the subsequent third PCR amplification. In the N-SOE method the

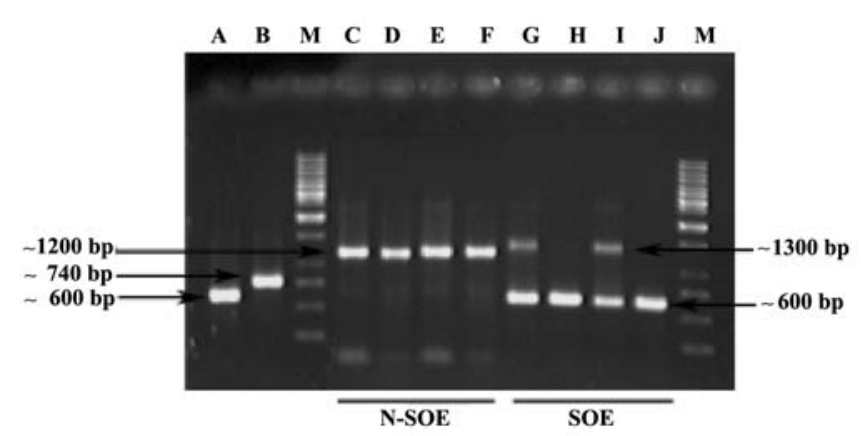

Figure 2. Agarose gel electrophoresis of the N-SOE and the corresponding SOE methods. Lanes A and B; PCR products of the first (using primer $\mathrm{A}$ and $\mathrm{F}, \sim 600 \mathrm{bp}$ ) and the second (using primers $\mathrm{E}$ and $\mathrm{B}, \sim 740 \mathrm{bp}$ ) PCRs. Lanes $\mathrm{C}$ to $\mathrm{F}$; results of the third PCR in N-SOE method using primer $\mathrm{C}$ and D ( 1200 bp). Lanes G to J; results of the third PCR in SOE method using primers A and B ( 1300 bp). Lanes M; $1 \mathrm{~kb}$ DNA ladder (Fermentas, Heidelberg, Germany). Nonspecific bands are only present in SOE but not in N-SOE method third PCR is performed by using $\mathrm{C}$ and $\mathrm{D}$ primers to obtain a $\sim 1200$ bp fragment (Figure 2B; lanes G-J), whereas in standard SOE method the third PCR is performed with the $A$ and $B$ primers to obtain a $\sim 1300 \mathrm{bp}$ fragment (Figure 2B; lanes G-J). The third PCR products of the N-SOE and the standard SOE method were cloned in $\mathrm{pTZ} 57 \mathrm{R} / \mathrm{T}$ to produce recombinant $\mathrm{pTA}-\mathrm{M}$ BTL2 plasmids. Subsequently, the presence of the mutation into the $b t l 2$ gene was confirmed by DNA sequencing (Data not shown). In N-SOE method, the product of the third PCR $(\sim 1200 \mathrm{bp})$ was slightly smaller than standard method ( 1300 bp). The reason was that gene specific primers were positioned in the interior part of the fragment, at least 50-70 bp apart far from it's both ends.

\section{Discussion}

Site-directed mutagenesis is a method that is used to make changes to the any gene. Until now, many techniques have been developed to improve the efficiency of mutagenesis. In this study the standard SOE method improved to increase the efficiency of mutagenesis of any gene. The expected fragments in the SOE and N-SOE methods were approximately 1300 and 1200 bp respectively. As we expected, using the NSOE method a single fragment of the correct size $(\sim 1200 \mathrm{bp})$ was amplified without any detectable background, whereas applying SOE method in addition to the expected fragment $(\sim 1300)$, an extra fragment ( $600 \mathrm{bp}$ ) was also amplified. (Figure 2, lanes $\mathrm{G}$ to $\mathrm{J}, 600 \mathrm{bp}$ fragment).

In the N-SOE method, similar to the conventional PCR, the specific or nested primers are added to the PCR master mix just in the first cycle of the third PCR, whereas in a standard SOE method primers are added to the PCR master mix after 10 cycles of the third PCR.

To summarize, in the N-SOE method ( $i$ ) using a set of additional primer, (ii) addition of gene specific primers ( $\mathrm{C}$ and $\mathrm{D}$ primers) to the PCR master mix just at the first cycle of third PCR and (iii) using extension temperature of $68^{\circ} \mathrm{C}$ instead of $72^{\circ} \mathrm{C}$ in first 10 cycles of the third PCR will result in an increased specificity of SOE method. These alterations in SOE make the method more productive and efficient in the experiments wherein site-directed mutagenesis will be subject of application.

\section{Acknowledgments}

We would like to thank H. Ahmadi Danesh for the valuable technical helps. 


\section{References}

1. Ling MM, Robinson BH. Approaches to DNA mutagenesis: an overview. Anal Biochem. 1997;254(2):157-178.

2. Kim YG, Maas S. Multiple site-directed mutagenesis in vitro. Methods Mol Biol. 2002;182:29-36. DOI: 10.1006/abio. 1997.2428

3. Ge L, Rudolph P. Simultaneous introduction of multiple mutations using overlap extension PCR. Biotechniques 1997;22(1):28-30.

4. Urban A, Neukirchen S, Jaeger KE. A rapid and efficient method for site-directed mutagenesis using one-step overlap extension PCR. Nucleic Acids Res. 1997;25(11):2227-2228. DOI: $10.1093 /$ nar/25.11.2227

5. Sambrook J, Russell DW (David W, Cold Spring Harbor Laboratory. Molecular cloning: a laboratory manual / Joseph Sambrook, David W. Russell. Cold Spring Harbor, N.Y: Cold Spring Harbor Laboratory; Cold Spring Harbor, N.Y.: Cold Spring Harbor Laboratory, c2001.

6. Peng RH, Xiong AS, Yao QH. A direct and efficient PAGEmediated overlap extension PCR method for gene multiplesite mutagenesis. Appl Microbiol Biotechnol. 2006;73(1):234240. DOI: 10.1007/s00253-006-0583-3

7. Xiao YH, Yin MH, Hou L, Luo M, Pei Y. Asymmetric overlap extension PCR method bypassing intermediate purification and the amplification of wild-type template in site-directed mutagenesis. Biotechnol Lett. 2007;29(6):925-930. DOI: 10.1007/s 10529-007-9327-4

8. Ho SN, Hunt HD, Horton RM, Pullen JK, Pease LR. Sitedirected mutagenesis by overlap extension using the polymerase chain reaction. Gene 1989;77(1):51-59. DOI: 10.1016/0378 1119(89)90358-2

9. Horton RM. In Vitro Recombination and Mutagenesis of DNA: SOEing Together Tailor-Made Genes. Methods Mol Biol Clifton NJ. 1993;15:251-261. DOI: 10.1385/0-89603-244-2:251 